\begin{tabular}{|c|c|c|}
\hline BIC & $\begin{array}{c}\text { BIODIK: Jurnal IImiah Pendidikan Biologi } \\
\text { ISSN 2580-0922 (online), ISSN 2460-2612 (print) } \\
\text { Volume 07, Nomor 04, Tahun 2021, Hal. 77-83 } \\
\text { Available online at: } \\
\text { https://online-journal.unja.ac.id/biodik }\end{array}$ & BIODIK Q \\
\hline
\end{tabular}

Research Article

\title{
Pengaruh Model Pembelajaran Inquiri Terbimbing dan Pemahaman Konsep Terhadap Kemampuan Pemecahan Masalah SMP Negeri 6 Kerinci
}

\section{(The Influence of Guided Inquiry Learning Model and Concept Understanding on Problem Solving Ability of SMP Negeri 6 Kerinci)}

Meri Mustika*, Revis Asra, Evita Anggereini

Program Magister Pendidikan IPA Universitas Jambi

JI. Raden Mattaher No.21, Ps. Jambi, Kec. Jambi Tim., Kota Jambi, Jambi 36123

${ }^{*}$ Correspondence email: Merimustika93@gmail.com

\begin{tabular}{|c|c|}
\hline Informasi Artikel & ABSTRACT \\
\hline \multirow{6}{*}{$\begin{array}{l}\text { Submit: } 23-07-2021 \\
\text { Diterima: } 28-11-2021 \\
\text { Dipublikasikan:20-12-2021 }\end{array}$} & This study aims to determine (1) the effect of the Guided Inquiry learning model \\
\hline & on students' problem-solving abilities; (2) the effect of Concept Understanding \\
\hline & $\begin{array}{l}\text { level on students' Problem Solving Ability; (3) the interaction between the Guided } \\
\text { Inquiry learning model and the level of Concept Understanding on students' }\end{array}$ \\
\hline & $\begin{array}{l}\text { Problem Solving Ability. This study uses a Quasi Experimental Design with a } \\
\text { pretest-posttest Control Group Design model. The population in this study was }\end{array}$ \\
\hline & $\begin{array}{l}\text { class VII SMP Negeri } 6 \text { Kerinci. The sample uses probability sampling which } \\
\text { includes random sampling. To collect the data used is a test of problem solving } \\
\text { skills, tests of understanding the concept and documentation. Data analysis used } \\
\text { Two-Way Anova. }\end{array}$ \\
\hline & Key words: Guided Inquiry Learning Model, Concept Understanding \\
\hline Penerbit & ABSTRAK \\
\hline \multirow{6}{*}{$\begin{array}{l}\text { Program Studi Pendidikan Biologi } \\
\text { FKIP Universitas Jambi, } \\
\text { Jambi- Indonesia }\end{array}$} & Penelitian ini bertujuan untuk mengetahui (1) pengaruh model pembelajaran \\
\hline & $\begin{array}{l}\text { Inquiri Terbimbing terhadap Kemampuan Pemecahan Masalah siswa; (2) } \\
\text { pengaruh tingkat Pemahaman Konsep terhadap Kemampuan Pemecahan }\end{array}$ \\
\hline & $\begin{array}{l}\text { Masalah siswa; (3) interaksi antara model pembelajaran Inquiri Terbimbing } \\
\text { dengan tingkat Pemahaman Konsep terhadap Kemampuan Pemecahan }\end{array}$ \\
\hline & $\begin{array}{l}\text { Masalah siswa. Penelitian ini menggunakan Quasi Eksperimental Design } \\
\text { dengan model pretest-posttest Control Group Design. Populasi pada penelitian } \\
\text { ini adalah kelas VII SMP Negeri } 6 \text { Kerinci. Sampelnya menggunakan probability }\end{array}$ \\
\hline & $\begin{array}{l}\text { Sampling yang meliputi Random Sampling. Untuk mengumpulkan data yang } \\
\text { digunakan adalah tes kemampuan pemecahan masalah, tes pemahaman } \\
\text { konsep serta dokumentasi. Analisis data yang digunakan Anava Dua Arah. }\end{array}$ \\
\hline & Kata kunci: Model Pembelajaran Inquiri Terbimbing, Pemahaman Konsep \\
\hline
\end{tabular}

This BIODIK : Jurnal IImiah Pendidikan Biologi is licensed under a CC BY-NC-SA (Creative Commons Attribution-ShareAlike 4.0 International License) 


\section{PENDAHULUAN}

Menurut Sanjaya (2008:200), pembelajaran inkuiri terbimbing adalah suatu model pembelajaran inkuiri dimana guru memberikan kepada siswa berbagai macam bimbingan atau instruksi. Beberapa rencana dibuat oleh guru, dan siswa belum membuat pertanyaan atau masalah. Dalam pembelajaran inkuiri terbimbing, guru tidak akan melepaskan kegiatan yang dilakukan oleh siswa. Guru harus membimbing dan membimbing siswa untuk melakukan kegiatan, agar siswa yang berpikir lambat atau siswa yang memiliki kecerdasan rendah tetap dapat mengikuti kegiatan yang sedang berlangsung, dan siswa yang berkemampuan berpikir tinggi tidak memonopoli kegiatan. Oleh karena itu, guru harus memiliki keterampilan manajemen kelas yang baik.

Penggunaan model pembelajaran inkuiri terbimbing dalam proses pembelajaran akan menimbulkan aktivitas siswa yang lebih banyak, karena siswa dituntut untuk dapat memecahkan masalah yang diterima melalui observasi. Dalam proses pembelajaran IPA, aktivitas siswa yang terjadi ketika menggunakan model pembelajaran inkuiri terbimbing juga didorong oleh pemahaman konseptual siswa terhadap kemampuannya dalam memecahkan masalah yang diberika model pembelajaran inkuiri memiliki beberapa keunggulan. Beberapa keuntungannya adalah merupakan model pembelajaran yang menekankan pada pengembangan kognisi, emosi, dan psikomotorik secara seimbang, sehingga pembelajaran melalui model ini dianggap lebih bermakn dan dapat menyediakan ruang belajar sesuai dengan gaya siswa. Kelebihan dari model pembelajaran ini adalah dapat memenuhi kebutuhan siswa dengan kemampuan di atas rata-rata. Artinya, siswa dengan kemampuan belajar yang baik tidak akan terhalang oleh siswa yang kemampuan belajarnya buruk.

\section{METODE PENELITIAN}

Penelitian ini adalah penelitian eksperimen, dengan desain True Exsperimental Design dalam penelitian ini terdapat tiga kelompok yang dipilih secara random, kemudian diberi pretest untuk mengetahui keadaan awal adakah perbedaan antara kelompok eksperimen dan kelompok kontrol. (Sugiyono, 2013: 75). Adapun jenis desain eksperimen yang digunakan pada penelitian ini yaitu pretespostest control group design sebagai berikut (Sugiyono, 2013: 76).

\section{Tabel 1. Pretest and Posttest Control Group Design}

$\begin{array}{lccc}\text { Kelompok } & \text { Pretest } & \text { Treatment } & \text { Posttest } \\ \text { Eksperimen } & \text { Y1 } & \text { X1 } & \text { Y2 } \\ \text { Kontrol } & \text { Y1 } & \text { X2 } & \text { Y2 }\end{array}$

$\begin{array}{lll}\begin{array}{l}\text { Keterangan: } \\ \text { Y1 }\end{array} & : \begin{array}{l}\text { Nilai tes awal diambil dari nilai tes kemampuan pemecahan masalah siswa yang diberikan } \\ \text { kepada setiap kelompok } \\ \text { Y2 }\end{array} \\ \text { X1 } & \begin{array}{l}\text { Nilai tes akhir yang merupakan tes kemampuan pemecahan siswa yang diberikan kepada } \\ \text { setiap kelompok }\end{array} \\ \text { X2 } & : \text { Model Pembelajaran Inquiri Terbimbing } \\ & : \text { Pembelajaran konvensional (metode ceramah, tugas kelompok, dan diskusi) }\end{array}$

Pada desain ini, kelompok eksprimen diberi perlakuan pembelajaran dengan menggunakan model pembelajaran Inquiri Terbimbing, dan kelompok kontrol dengan pembelajaran konvensional (metode ceramah, tugas kelompok, dan diskusi), kemudian masing-masing kelompok diberi pre-test untuk melihat skor kemampuan pemecahan masalah siswa sebelum perlakuan dan post-test untuk melihat skor kemampuan pemecahan masalah siswa setelah perlakuan.

Variabel dalam penelitian ini terdiri dari variabel bebas, variabel terikat dan variable moderat, adapun variable tersebut yaitu:

1. Variabel bebas : model pembelajaran Inquiri Terbimbing

2. Variabel terikat : Kemampuan Pemecahan Masalah siswa 
3. Variabel moderator : tingkatan Pemahaman Konsep siswa

Keterkaitan antara variabel bebas, terikat dan moderator tersebut di sajkan dalam matrik $2 \times 2$ dalam model Wainer dapat dilihat pada table 2.

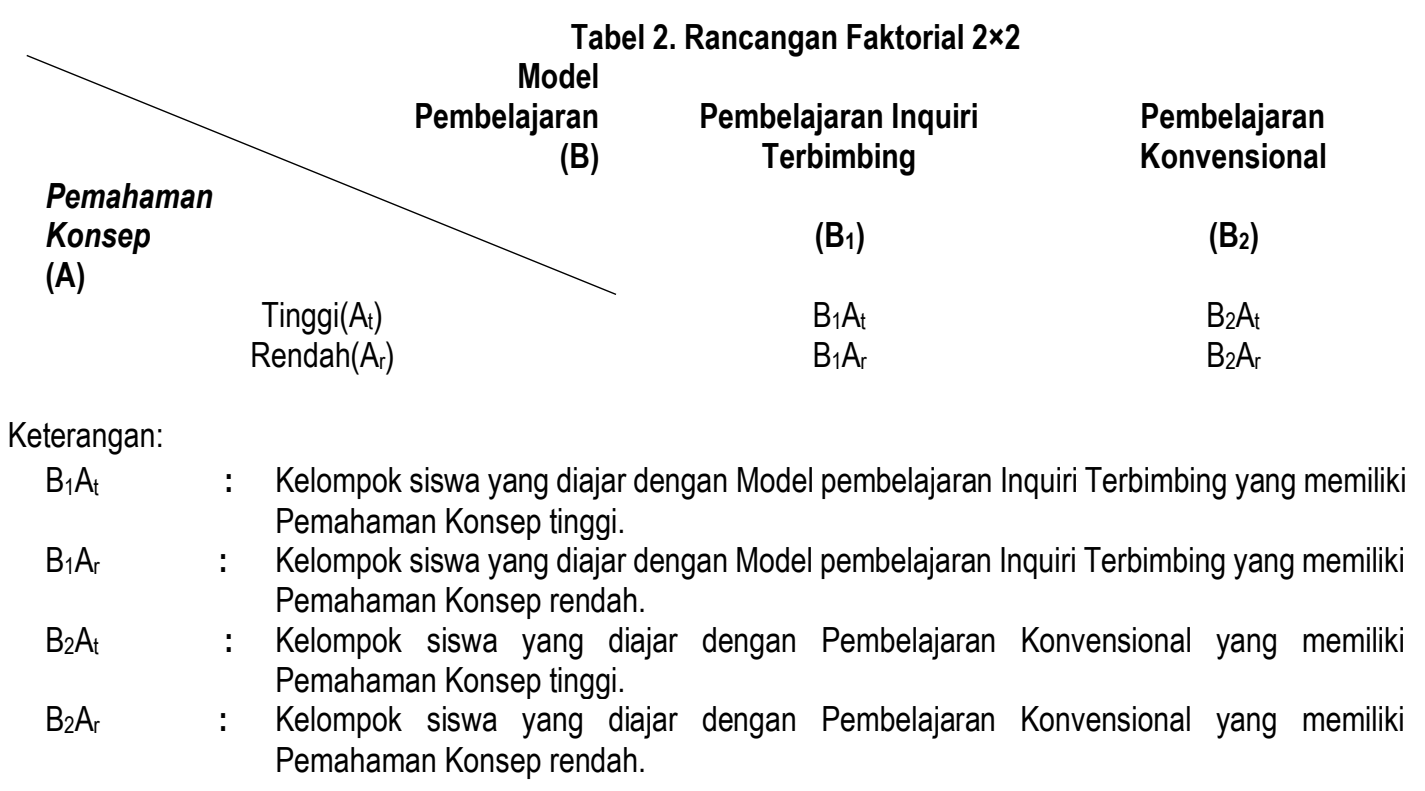

\section{HASIL PENELITIAN DAN PEMBAHASAN}

Kemampuan pemecahan masalah siswa yang dilakukan di SMP Negeri 6 Kerinci. Sebelum Pretest dan Post-test yang tes kemampuan pemecahan masalah siswa dilakukan terlebih dahulu diuji cobakan terhadap kelas yang bukan sampel. Soal uji coba sebanyak 10 soal, setelah mendapatkan hasil kemudian dianalisis sehingga soal Pre-test dan Post-test tetap menjadi 10 soal. Desain penelitian yang digunakan adalah Quasi-Eksperimental Design dengan rancangan nonequivalen pre-test and post-test control group design. Keterkaitan antara variabel bebas dan terikat disajikan dalam matrik 2×2, maka penelitian ini dilakukan pada dua kelas untuk dijadikan sebagai sampel penelitian yaitu 1 kelas eksperimen yaitu kelas VIIC dan 1 kelas kontrol yaitu kelas VIIA. Sebelum perlakuan, terlebih dahulu peneliti menyebarkan soal pemahaman konsep yang telah divalidasi oleh dosen ahli yang bertujuan untuk mengetahui tingkat kemampuan pemahaman konsep siswa. Kemudian, menyebarkan soal Pretest kemampuan pemecahan masalah siswa kepada kedua kelas sampel untuk mengetahui kemampuan awal siswa. Pada proses pembelajaran, kelas eksperimen dan kelas kontrol melaksanakan pembelajaran masing-masing 3 kali pertemuan dengan materi yang sama dan model pembelajaran yang berbeda. Kelas eksperimen adalah kelas VIIC menggunakan model pembelajaran Inkuiri Terbimbing, serta kelas kontrol adalah kelas VIIA yang pembelajarannya menggunakam model konvensional yang ditambah (Metode ceramah, diskusi, dan penugasan).

Pokok pembahsan yaitu Klasifikasi Makhluk Hidup. Setelah materi selesai diajarkan kepada kelas eksperimen dan kelas kontrol dengan perlakuan yang berbeda pada setiap kelas, selanjutnya diberikan tes akhir (post-test) kemampuan pemecahan masalah siswa yang berbentuk uraian dengan soal yang sama untuk masing-masing kelas. 


\section{Hasil Tes Kemampuan Pemecahan Masalah Siswa Kelas Eksperimen dan Kelas Kontrol}

Kemampuan pemecahan masalah siswa diukur berdasarkan hasil tes dengan soal uraian yang memenuhi indikator kemampuan pemecahan masalah siswa yaitu memahami masalah, merencanakan penyelesaian, melaksanakan penyelesaian, dan memeriksa kembali. Tes kemampuan pemecahan masalah siswa diberikan kepada kelas eksperimen dengan menggunakan model pembelajaran Inkuiri Terbimbing, sedangkan kelas kontrol menggunakan model pembelajaran konvensional.

Berdasarkan tabel di atas, dapat dilihat bahwa nilai tertinggi dan nilai terendah pada kelas dengan model pembelajaran Inkuiri Terbimbing masing-masing adalah 99 dan 78, dan pada kelas dengan pembelajaran konvensional masing-masing adalah 89 dan 75 . Nilai rata-rata untuk kelas dengan model pembelajaran Inkuiri Terbimbing sebesar 88,15 , sedangakan kelas kontrol dengan pembelajaran konvensional ditambah media sebesar 81,87 . Nilai rata-rata ini diperoleh dari penjumlahan dari keseluruhan data yang diperoleh dari setiap kelas kemudian dibagi dengan banyaknya jumlah siswa dalam setiap kelas tersebut.

Untuk kemiringan pada kelas yang menggunakan model pembelajaran Inkuiri Terbimbing sebesar 0,068, sedangkan pada kelas model pembelajaran konvensional sebesar $-0,010$. Untuk keruncingan pada kelas yang menggunakan model pembelajaran Inkuiri Terbimbing sebesar 0,130, dan pada kelas dengan pembelajaran Konvensional sebesar $-0,555$. Nilai rata-rata post-test untuk setiap kelas dapat dilihat pada gambar 1.

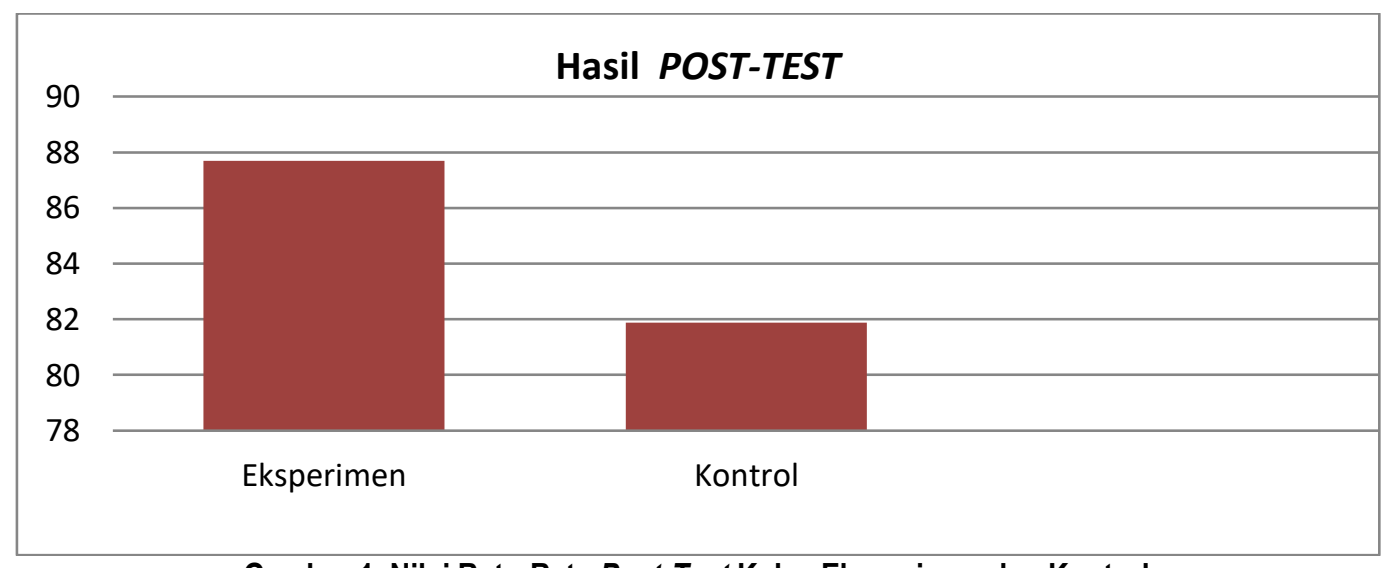

Gambar 1. Nilai Rata-Rata Post-Test Kelas Eksperimen dan Kontrol

Sari, Y. P., \& Masri, M. (2020) mengemukakan hasil penelitiannya bahwa model inquiry terbimbing dapat meningkatkan kemampuan pemecahan masalah yang lebih tinggi dibandingkan dengan model yang lain. Lewa, I. W. L. (2017) juga mendukung dengan hasil penelitiannya yang menyatakan bahwa implementasi model pembelajaran inkuiri terbimbing berpengaruh terhadap kemampuan pemecahan masalah sebesar $30 \%$ dan berpengaruh positif terhadap kemampuan berkomunikasi sebesar $12,75 \%$. Sayyadi, M., Hidayat, A., \& Muhardjito, M. (2016) mengungkapkan bahwa model pembelajaran inkuiri terbimbing berpengaruh terhadap peningkatan kemampuan pemecahan masalah siswa pada kelas eksperimen di banding pada kelas kontrol yang tidak menggunakan model inkuiri terbimbing. 


\section{Hasil Soal Pemahaman Konsep Siswa kelas Eksperimen dan Kelas Kontrol}

Skor tertinggi dan skor terendah porelehan skor pemahaman konsep Kelas eksperimen 1 yakni kelas yang menggunakan model pembelajaran Inkuiri Terbimbing masing-masing adalah 79 dan 26, dan pada kelas kontrol yakni kelas yang menggunakan model konvensional masing-masing adalah 82 dan 26. skor rata-rata tingkat pemahaman konsep siswa untuk kelas eksperimen adalah 56,15 , dan kelas kontrol adalah 55,14. Standar deviasi pada kelas eksperimen sebesar 15,686, dan pada kelas kontrol sebesar 14,961. Sedangkan untuk varians, untuk kelas eksperimen adalah 246,055 , dan untuk kelas kontrol adalah 223,831 . Untuk kemiringan pada kelas eksperimen sebesar,- 640 , sedangkan pada kelas kontrol sebesar,- 668 . Untuk keruncingan pada kelas eksperimen adalah,- 887 , sedangkan pada kelas kontrol adalah ,858.

Annafy, N., Perkasa, M., Agustina, S., \& Sari, E. P. (2021) menyatakan bahwa terdapat pengaruh model inkuri terbimbing terhadap pemahaman konsep siswa. Hariani, N. R., Nuswowati, M., \& Winarno, W. (2020) mengungkapkan bahwa berdasarkan hasil penelitiannya terdapat pengaruh model pembelajaran inkuiri terbimbing dengan bantuan e-modul terhadap pemahaman konsep siswa. Aryani, P. R., Akhlis, I., \& Subali, B. (2019) juga mendukung dengan hasil penelitiannya yang menyatakan bahwa model inkuiri terbimbing dibantu dengan media augmated reality berpengaruh terhadap pemahaman konsep siswa.

\section{SIMPULAN}

1.) Pada variabel model pembelajaran, diperoleh nilai sig. $=0,000<0,05$ sehingga $\mathrm{H}_{0}$ ditolak, $\mathrm{H}_{1}$ diterima. Dengan demikian, untuk hipotesis pertama dapat disimpulkan bahwa terdapat pengaruh model pembelajaran Inquiri terbimbing terhadap kemampuan pemecahan masalah siswa kelas VII SMP Negeri 6 Kerinci. 2.)Pada variabel Tingkat Pemahaman Konsep Siswa, diperoleh nilai sig. $=0,232<0,05$ sehingga $\mathrm{H}_{0}$ diterima, $\mathrm{H}_{1}$ ditolak. Dengan demikian, untuk hipotesis kedua dapat disimpulkan bahwa tidak terdapat pengaruh pemahaman konsep terhadap kemampuan pemecahan masalah siswa. kelas VII SMP Negeri 6 Kerinci.3.)Pada variabel Interaksi Model Pembelajaran dengan Tingkat Pemahaman Konsep Siswa diperoleh nilai sig. $=0,615>0,05$ sehingga $\mathrm{H}_{0}$ ditolak, $\mathrm{H}_{1}$ diterima. Dengan demikian, untuk hipotesis ketiga dapat disimpulkan bahwaterdapat interaksi antara model pembelajaran Inquiri terbimbing dengan pemahaman konsep terhadap kemampuan pemecahan masalah siswa kelas VII SMP Negeri 6 Kerinci.

\section{RUJUKAN}

Abdurrahman, Mulyono. 2009. Pendidikan Bagi Anak yang Berkesulitan Belajar. Jakarta: Rineka Cipta Annafy, N., Perkasa, M., Agustina, S., \& Sari, E. P. (2021). Pengaruh Model Pembelajaran Inquiry Terbimbing Terhadap Pemahaman Konsep Kimia Siswa Di Man 2 Kota Bima Tahunpelajaran 2019/2020. Jurnal Redoks (Jurnal Pendidikan Kimia Dan Ilmu Kimia), 4(1), 17-24.

Agustiana, I Gusti Ayu Tri. 2014. Konsep Dasar IPA Aspek Biologi. Yoyakarta: Ombak Aly, Abdullah. 2008. Ilmu Alamiah Dasar. Jakarta: Bumi Aksara

Amri Sofan, dkk. 2010. Proses Pembelajaran Kreatif dan Inofatif dalam Kelas. Jakarta: Prestasi Pustaka Aryani, P. R., Akhlis, I., \& Subali, B. (2019). Penerapan model pembelajaran inkuiri terbimbing berbentuk augmented reality pada peserta didik untuk meningkatkan minat dan pemahaman konsep ipa. UPEJ Unnes Physics Education Journal, 8(2), 90-101.

Arikunto, Suharsimi. 2010. Prosedur Penelitian. Jakarta: Rineka Cipta.

Buxton \& Eugene. 2007. Teaching Science in Elementary \& Middle School: A Cognitive and Cultural Approch. SAGE Publications: California.

Cahyono. 2010. Model-model Pembelajaran. Semarang: Rineka Cipta. 
Chiappetta dan Koballa. 2010. Science Instruction in The Middle and Secondary Schools: Developing Fundamental Knowledge and Skills. United State of America: Pearson Education Inc.

Dina Agustina, dkk. 2014. Penerapan Strategi Pemecahan Masalah Untuk Meningkatkan Kemampuan Pemecahan Masalah Matematis Siswa Kelas VIII SMP Negeri 7 Padang". Jurnal Pendidikan Matematika 3 (2): 20-24.

Erman Suherman, dkk. 2003. Strategi Pembelajaran matematika Kontemporer. Bandung: JICA Gulo, W. 2008 Strategi Belajar Mengajar. Jakarta: Grafindo

Hamalik, Oemar. 2008. Perencanaan Pengajaran Berdasarkan Pendekatan Sistem. Jakarta: Bumi Aksara

Hamdani. 2010. Strategi Belajar Mengajar. Bandung: CV. Pustaka Setia

Hariani, N. R., Nuswowati, M., \& Winarno, W. (2020). Pengaruh penerapan model inkuiri terbimbing berbantuan e-modul terhadap pemahaman konsep hidrolisis garam. Jurnal Inovasi Pendidikan Kimia, 14(1), 2561-2571.

Herman, Hudojo. 2005. Pengembangan Kurikulum dan Pembelajaran Matematika. Malang: IKIP

Ikhwan Zulkarnain dan Hadi Budiman. 2019. Pengaruh Pemahaman Konsep terhadap Kemampuan Pemecahan Masalah Matematika. Research and Development Journal Of Education Vol. 6 No. 1|p-ISSN 2406-9744 e-ISSN 2657-1056. Pendidikan Matematika, FMIPA Universitas Indraprasta PGRI Jakarta.

I Made Alit M. dan Wandy. 2009. Hakikat IPA dan Pendidikan IPA. Bandung: P4TK

Ismira Wahyu Lestari Lewa, dkk. 2018. Implementasi Model Pembelajaran Inkuiri Terbimbing pada Kemampuan Pemecahan Masalah Fisika dan Kemampuan Komunikasi Siswa SMP. Unnes Physics Education Journal No. 7 (2) ISSN 2252-6935. Jurusan Fisika, Fakultas Matematika dan Ilmu Pengetahuan Alam, Universitas Negeri Semarang.

Ismawati, H. 2007. Skripsi: Meningkatkan Aktivitas dan Hasil Be/ajar Sains-Fisika Me/alui Pembelajaran Inquiri Terbimbing Untuk Sub Pokok Bahasan Pemantulan Cahaya pada Siswa Kelas VIII SMP Negeri 13 Semarang Tahun Pelajaran 2006/2007. Universitas Negeri Semarang.

Jacob. 2010. Matematika Sebagai Pemecahan Masalah. Bandung: Setia Budi

Jacob, C. 2011. Pemecahan Masalah Sebagai Suatu Tujuan, Proses dan Keterampilan Dasar. Jakarta: Jurnal Universitas Pendidikan Indonesia

Joseph, Arbuscato. 1995. Teaching Children Science: A Discover Approach Fourth Edition. US: A Simon \& Schuster Company

Kemendiknas. 2011. Pedoman Pelaksanaan Pendidikan Karakter. Jakarta: Pusat Kurikulum Perbukuan. Kurnia Eka Lestari, dkk. 2015. Penelitian Pendidikan Matematika. Bandung: PT. Refika Aditama Lestari dan Yudhanegara. 2015. Penelitian Pendidikan Matematika. Bandung: PT. Refika Aditama

Lewa, I. W. L. (2017). Implementasi Model Pembelajaran Inkuiri Terbimbing pada Kemampuan Pemecahan Masalah Fisika dan Kemampuan Komunikasi Siswa SMP (Doctoral dissertation, Universitas Negeri Semarang).

Nupita, Evi. 2013. Penerapan model pembelajaran penemuan terbimbing untuk meningkatkan hasil belajar dan keterampilan pemecahan masalah IPA pada siswa kelas V Sekolah Dasar. Jurnal PGSD Volume 01 Nomor 02.

Permendiknas No.14 Th 2007 tentang Standar Isi Paket A B C.

Prambudi, Kuswandi. 2010. Model Inquiri Terbimbing. Jakarta: Kencana Prenada Media Grup.

Purwanto, Ngalim. 2007. Psikologi Pendidikan. Bandung: PT Remaja Rosdakarya

Puskur, Balitbang. 2010. Pendidikan Karakter di Sekolah Menengah Pertama. Jakarta : Rineka Cipta

Ramlawati, dkk. 2017. Sumber Belajar Penunjang PLPG 2017 Mata Pelajaran IPA BAB II Klasifikasi Makhluk hldup. Jakarta: Kemendikbud Direktorat Jenderal Guru dan Tenaga Kependidikan

Risnawati. 2008. Strategi Pembelajaran Matematika. Pekanbaru: Suska Press.

Sanjaya, Wina. 2008. Perencanaan dan desain sistem pembelajaran. Jakarta: Kencana Prenada Media Group. 
Sari, Y. P., \& Masri, M. (2020). Kemampuan Pemecahan Masalah Matematis Model Pembelajaran Inquiri Terbimbing Dan Means Ends Analysis. Jurnal Math-UMB. EDU, 7(2).

Sardiman. 2010. Interaksi dan Motivasi Belajar Mengajar. Jakarta: PT. Raja Grafindo Persada

Sardiman. 2011. Interaksi \& Motivasi Belajar Mengajar Cet. Ke-20. Jakarta: Raja Grafindo Persada.

Sayyadi, M., Hidayat, A., \& Muhardjito, M. (2016). Pengaruh strategi pembelajaran inkuiri terbimbing dan terhadap kemampuan pemecahan masalah fisika pada materi suhu dan kalor dilihat dari kemampuan awal siswa. Jurnal Inspirasi Pendidikan, 6(2), 866-875.

Sitiatava, Rizema. 2013. Desain Belajar Mengajar Kreatif Berbasis Sains. Jogjakarta: Diva Press.

Sudjana, Nana. 2009. Penilaian Hasil Proses Belajar Mengajar. Bandung: Remaja Rosdakarya

Sugiyono. 2013. Metode Penelitian Kuantitatif, Kualitatif, dan R\&D. Bandung: Alfabeta

Suparno, Paul. 2013. Metodologi Pembelajaran Fisika. Jakarta: Diandra Piramita

Taniredja dan Mustafidah. 2011. Penelitian Kuantitatif (Sebuah Pengantar). Bandung: Alfabeta.

Undang-undang SISDIKNAS Nomor 20 Tahun 2003 tentang Pendidikan Nasional.

Wahono Widodo, dkk. 2017. IImu Pengetahuan Alam (IPA) kelas VII Semester I. Jakarta: Kementerian Pendidikan dan Kebudayaan Republik Indonesia

Widhiarso, Wahyu. 2010. Pengembangan Skala Psikologi. Universitas Gajah Mada Press. 